\title{
Quantification of Protein Kinase A (PKA) Activity by An in vitro Radioactive Assay Using the Mouse Sperm Derived Enzyme \\ Cintia Stival ${ }^{1, *}$, Carolina Baro Graf ${ }^{1}$, Pablo E. Visconti ${ }^{2}$ and Dario Krapf ${ }^{1, *}$
}

${ }^{1}$ Laboratory of Cell Signal Transduction Networks, Instituto de Biología Molecular y Celular de Rosario (IBR), CONICET-UNR, Rosario 2000, Argentina; ${ }^{2}$ Department of Veterinary and Animal Sciences, University of Massachusetts, 01003 Amherst, Massachusetts, USA

*For correspondence: krapf@ibr-conicet.gov.ar; stival@ibr-conicet.gov.ar

\begin{abstract}
[Abstract] In order to acquire fertilizing potential, mammalian sperm must undergo a process known as capacitation, which relies on the early activation of Protein Kinase A (PKA). Frequently, PKA activity is assessed in whole-cell experiments by analyzing the phosphorylation status of its substrates in a western-blot. This technique faces two main disadvantages: it is not a direct measure of the kinase activity and it is a time-consuming approach. However, since PKA can be readily obtained from sperm extracts, in vitro assays such as the "radioactive assay" can be performed using the native enzyme. Unlike western-blot, the radioactive assay is a straightforward technique to evaluate PKA activity by quantification of incorporated ${ }^{32} \mathrm{P}$ into a peptidic substrate. This approach easily allows the analysis of different agonists or antagonists of PKA. Since mouse sperm is a rich source of soluble PKA, this assay allows a simple fractionation that renders PKA usable both for in vitro testing of drugs on PKA activity and for following changes of PKA activity during the onset of capacitation.
\end{abstract}

Keywords: Protein Kinase A (PKA), Capacitation, Sperm, Kinase activity assay, Fertilization

[Background] Mammalian sperm are not able to fertilize an oocyte immediately after ejaculation. In order to acquire fertilization competence, they must undergo a series of cellular changes collectively known as capacitation (Stival et al., 2016). This process takes place within the female reproductive tract but can be emulated in the laboratory by incubating spermatozoa in a defined medium containing $\mathrm{Ca}^{2+}$, albumin and $\mathrm{HCO}_{3}{ }^{-}$, i.e., the "capacitation medium" (Visconti et al., 1995). Both $\mathrm{HCO}_{3}{ }^{-}$and $\mathrm{Ca}^{2+}$ act synergistically on a soluble adenylyl cyclase (SAC), producing an elevation of intracellular cAMP levels. Among different targets, cAMP directly activates the Ser/Thr Protein Kinase A (PKA), which acts as a central player orchestrating capacitation signaling events (Buffone et al., 2014). Usually, two different approaches can be used to analyze its activity. One of them relies on western-blots, using commercially available antibodies that detect a consensus phosphorylation sequence of PKA (Krapf et al., 2010). However, the steady-state phosphorylation status of any protein depends on the relative activities of both kinases and phosphatases acting on it. Thus, this approach fails to directly analyze actual PKA activity. A second approach involves measuring in vitro PKA activity by direct quantification of ${ }^{32} \mathrm{P}$ incorporated into a peptidic substrate, in a controlled reaction mixture containing phosphatase inhibitors (Stival et al., 2018). This allows analysis of PKA independently of other factors that could modulate the phosphorylated state of the substrate. The chemical nature of the peptidic substrate 
named Kemptide, named after Dr Kemp, who first synthesized it in 1977 (Kemp et al., 1977), includes a phosphorylable serine residue and two arginine on positions -3 and -2 , allowing high PKA specificity. In addition, the Kemptide possesses high relative positive charge which accounts for its strong binding to the negatively charged Whatman P81 cellulose paper, simplifying washing of excess radioactive material (Kemp et al., 1977). The enzyme PKA is composed by two regulatory and two catalytic subunits (Akamine et al., 2003; Zhang et al., 2012). Both types of subunits can be found in Triton X-100-soluble and -insoluble fractions of mouse sperm (Visconti et al., 1997). The activity of PKA within the soluble fraction increases during sperm capacitation. However, the activity of PKA that remains in the insoluble fraction does not change during the course of capacitation, and thus, acts as an excellent source of PKA for enzymatic studies (Visconti et al., 1997).

The protocol described herein is used to analyze the effect of agonists or antagonists on PKA activity, using mouse sperm as the source for the kinase, lowering costs while keeping high efficiency. However, this protocol can be easily adapted to analyze variations of PKA activity during the course of sperm capacitation, by using total unfractionated sperm extracts. In this regard, phosphorylation of the Kemptide reflects the given activity of PKA at any stage of capacitation.

Finally, other sources of PKA can also be used, such as purified PKA from plasmid expression.

\section{Materials and Reagents}

Note: Unless specified, all reagents are stored at room temperature $\left(R T, 15-25^{\circ} \mathrm{C}\right)$.

1. P81 Whatman cellulose chromatography paper (Sigma-Aldrich, catalog number: Z753645), in $2 \times 2 \mathrm{~cm}$ pieces

Note: There should be as many squares as conditions, plus 9 extra squares for controls, all in triplicates. All pieces should be labeled with a pencil to differentiate them after washing.

2. $7 \mathrm{ml}$ Copolymer Plastic Vial, Unlined White Poly Screw Cap (RPI, catalog number: 125509)

3. Eppendorf tube $(1.5 \mathrm{ml}$ and $2 \mathrm{ml})$

4. $0.45 \mu \mathrm{m}$ filter

5. Male mouse (8-20 weeks old)

6. $70 \%$ ethanol

7. Tris(hydroxymethyl)aminomethane (Tris base) (Cicarelli, catalog number: 1131214)

8. Triton X-100 (Neo Lab, catalog number: 01685)

9. $\mathrm{NaCl}$ (Cicarelli, catalog number: 750$)$

10. $\mathrm{MgCl}_{2}$ (Sigma-Aldrich, catalog number: M8266)

11. Adenosine $5^{\prime}$-triphosphate disodium salt hydrate (ATP) (Sigma-Aldrich, catalog number: A7699), store at $-20^{\circ} \mathrm{C}$

12. Sodium orthovanadate $\left(\mathrm{Na}_{3} \mathrm{VO}_{4}\right)$ (Sigma-Aldrich, catalog number: 450243$)$, store at $-20{ }^{\circ} \mathrm{C}$

13. $\beta$-Glycerophosphate disodium salt hydrate (G3P) (Sigma-Aldrich, catalog number: G6251), store at $-20^{\circ} \mathrm{C}$

14. Para-Nitrophenyl Phosphate (NPP) (Cayman chemicals, catalog number: 400090) 
15. cOmplete ${ }^{\mathrm{TM}}$, EDTA-free Protease Inhibitor Cocktail (Protease Cocktail) (Roche, catalog number: 4693132001), store at $4{ }^{\circ} \mathrm{C}$

16. Bovine Serum Albumin fatty-acid free (BSA) (Sigma-Aldrich, catalog number: A7906), store at $4{ }^{\circ} \mathrm{C}$

17. Adenosine $3^{\prime}, 5^{\prime}$-cyclic monophosphate sodium salt monohydrate (cAMP) (Sigma-Aldrich, catalog number: 3A6885), alternatively, 8-BrcAMP or db-cAMP can be used, store at $-20{ }^{\circ} \mathrm{C}$

18. 3-Isobutyl-1-methylxanthine (IBMX) (Sigma-Aldrich, catalog number: I5879), store at $-20{ }^{\circ} \mathrm{C}$

19. Kemptide (Leu-Arg-Arg-Ala-Ser-Leu-Gly) (Sigma-Aldrich, catalog number: K1127), store at $-20^{\circ} \mathrm{C}$

20. HEPES (Sigma-Aldrich, catalog number: H3375)

21. Trichloroacetic acid (TCA) (BioChemica, catalog number: PAA1431)

22. ortho-Phosphoric acid $85 \%$ (Merck, catalog number: 100573)

23. ATP (ATP_-32Py) $3000 \mathrm{Ci} / \mathrm{mmol} ; 10 \mathrm{mCi} / \mathrm{ml}$ (Perkin Elmer, catalog number: BLU502A)

24. Specific drugs to be tested in the experiment (inhibitors, agonists, etc.)

25. $\mathrm{KCl}$ (Sigma-Aldrich, catalog number: S-7653)

26. Na-Pyruvate (Sigma-Aldrich, catalog number: P-4562)

27. $\mathrm{CaCl}_{2} \cdot 2 \mathrm{H}_{2} \mathrm{O}$ (Sigma-Aldrich, catalog number: C-7902)

28. $\mathrm{KH}_{2} \mathrm{PO}_{4}$ (Sigma-Aldrich, catalog number: $\mathrm{P}-5655$ )

29. $\mathrm{MgSO}_{4} \cdot 7 \mathrm{H}_{2} \mathrm{O}$ (Sigma-Aldrich, catalog number: 63138 )

30. Glucose (Sigma-Aldrich, catalog number: G-6152)

31. DMSO (Sigma-Aldrich, catalog number: D2650)

\section{Solutions}

For detailed instructions on how to prepare the following solutions, refer to the Recipes heading:

1. $1 \mathrm{M}$ Tris $\mathrm{pH} 7.4$

2. $3 \mathrm{M} \mathrm{NaCl}$

3. $1 \mathrm{M} \mathrm{MgCl}_{2}$

4. $1 \mathrm{mM}$ ATP

5. $100 \mathrm{mM} \mathrm{Na}_{3} \mathrm{VO}_{4}$

6. $800 \mathrm{mM}$ Glyceraldehyde 3-phosphate (G3P)

7. $500 \mathrm{mM} p$-Nitrophenyl Phosphate (NPP)

8. $50 \mathrm{mg} / \mathrm{ml} \mathrm{BSA}$

9. $5 \mathrm{mM}$ Kemptide

10. $200 \mathrm{mM}$ HEPES $\mathrm{pH} 7.3$

11. $40 \%$ TCA

12. $5 \mathrm{mM}$ Ortho phosphoric acid

13. H-TYH medium (see Recipes)

14. Lysis buffer (see Recipes)

15. $100 \mathrm{mM}$ IBMX (see Recipes) 
16. Kinase buffer (see Recipes)

\section{Equipment}

1. Scintillation Counter (LKB Wallac Rackbeta 1209, catalog number: 090161)

2. Neubauer chamber

3. Surgery scissors (WPI, catalog number: 14393)

4. Tweezers

5. Orbital shake

6. Incubator

7. Centrifuge

\section{Software}

1. Microsoft ${ }^{\circledR}$ Office Excel (Microsoft Office 365), or similar

\section{Procedure}

A. Prepare Lysis buffer (Recipe 2) on the day of use. Leave the protease inhibitor cocktail to be added just before usage. Keep buffer on ice.

B. Calculate the volume of Kinase buffer that will be needed, considering $10 \mu \mathrm{l}$ per reaction tube, and taking into account that each condition (and controls) will be performed in triplicates. While prepare Kinase buffer (Recipe 4) adding all components but Kemptide, protease inhibitors, and ATP_ ${ }^{32} \mathrm{PY}$, which will be added before use.

C. Isolate the insoluble PKA fraction from mouse sperm extracts Note: This section describes how to obtain PKA from the Triton-insoluble fraction of mouse sperm extracts, to be used as source of PKA in the activity assay.

1. Euthanize 1 male mouse (8-20 weeks old) and perform surgery to extract the cauda regions from both epididymides (Figure 1). To do this:

a. Lay the euthanized mouse dorsally on a dissection board.

b. Spray the ventral area with $70 \%$ ethanol to prevent dry hair from detaching

c. Using scissors, incise the skin and muscle tissue from the abdominal wall, exposing the lower abdominal viscera (Figure $1 \mathrm{~A}$ ).

d. Using forceps, remove the fat pads that cover the testis to get the epididymis exposed (Figure 1A). 
e. Identify the epididymis attached to the testis, excise it, and localize the cauda region (Figure 1B, red area). Remove it from the caput and corpus regions (Figure 1B grey area), and adipose tissue (Figure 1B blue area).

f. While holding the cauda with forceps, perform 3 to 4 incisions, using surgery scissors (Figure 1C).

2. Place both epididymides in a round-bottom $2 \mathrm{ml}$ Eppendorf containing $500 \mu \mathrm{l}$ of H-TYH medium (Figure 1D) and incubate for $15 \mathrm{~min}$ at $37^{\circ} \mathrm{C}$.
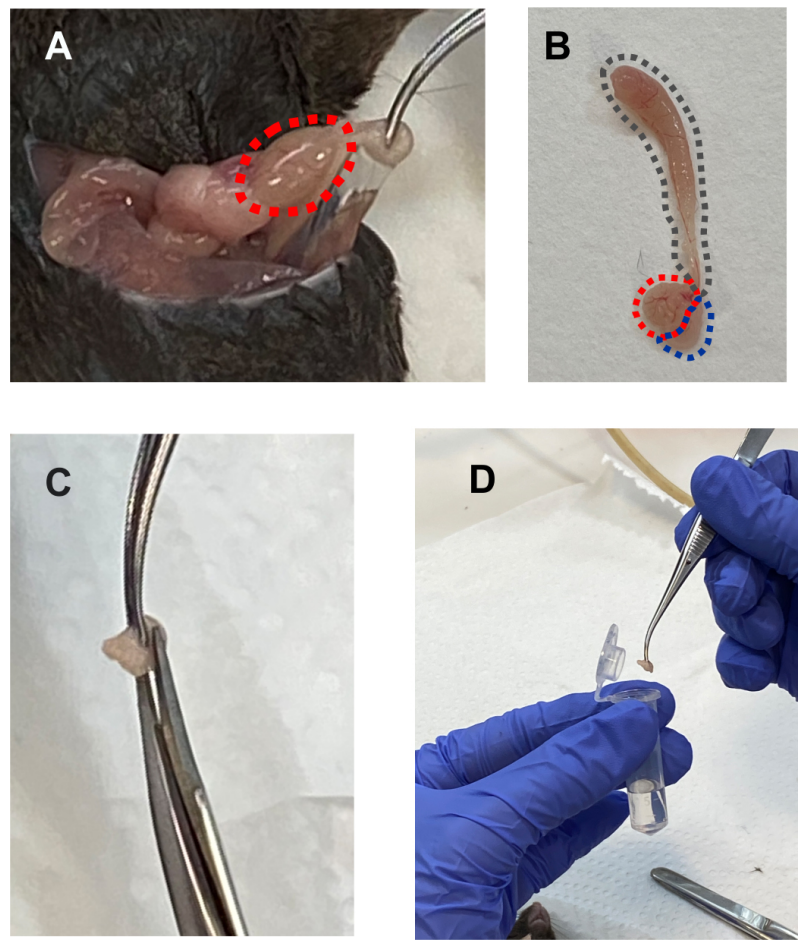

Figure 1. Sperm preparation. A. Ventral incision to excise the epididymis. Note the tweezers holding the cauda epididymis, attached to the testicle (red circled). B. Whole epididymis excised. Red, cauda; grey, caput and corpus; blue, adipose tissue. The cauda region is used for sperm swim out. C. Three to four incisions should be performed in each cauda, before allowing the sperm to swim out. D. Place both epididymides in a round-bottom Eppendorf tube containing $500 \mu \mathrm{l}$ of $\mathrm{H}$-TYH medium.

3. Transfer the sperm suspension $(500 \mu \mathrm{l})$ to a new round-bottom $2 \mathrm{ml}$ Eppendorf tube, leaving the epididymides behind.

4. Check sperm concentration by counting in a Neubauer chamber. Adjust concentration to $25 \mathrm{x}$ $10^{6} \mathrm{sperm} / \mathrm{ml}$ in $\mathrm{H}-\mathrm{TYH}$ medium.

5. Transfer the swim-out to a $1.5 \mathrm{ml}$ Eppendorf tube.

6. Centrifuge the sperm suspension at $10,000 \times g$ for $3 \mathrm{~min}$ at RT 
7. Discard supernatant. If the amount of swim out was of $25 \times 10^{6}$ sperm in $1 \mathrm{ml}$, resuspend the pellet in $330 \mu \mathrm{l}$ of ice-cooled Lysis buffer supplemented with protease inhibitor cocktail before use. If a different amount of sperm is used, modify buffer addition accordingly.

8. Incubate cells in Lysis buffer on ice for $30 \mathrm{~min}$

9. Centrifuge cells at $10,000 \times \mathrm{g}$ for $10 \mathrm{~min}$ at $4{ }^{\circ} \mathrm{C}$.

10. Discard supernatant and resuspend the pellet in $330 \mu \mathrm{l}$ of Lysis buffer (or same amount used in Step (7), with freshly added protease inhibitor cocktail. This fraction contains PKA. Each condition with $10 \mu \mathrm{l}$ of fraction will have the soluble PKA fraction extracted from $7.5 \times 10^{5}$ sperm. Consider that a minimum of $1.5 \times 10^{5}$ sperm are needed for each condition, which should be tested in triplicate.

11. Keep on ice for PKA activity assays. From now on this fraction is called PKA fraction.

D. Kinase reaction assay

1. Consider as many tubes as needed, keeping in mind that each condition should be performed in experimental triplicates, plus the following controls:

a. Negative control: it contains all the reaction reagents except for PKA fraction, which is replaced by Lysis buffer. It is used to determine the amount of Kemptide that is marked by ${ }^{32} \mathrm{P}$ in the absence of PKA.

b. Positive control: it is a control of maximum PKA activity, i.e., in the presence of $1 \mathrm{mM}$ cAMP and $100 \mu \mathrm{M}$ IBMX.

2. Add $10 \mu$ of Lysis buffer containing any drug to be analyzed. Consider that it will be diluted $3 x$ at the time of the reaction. Whatever drug to be tested must be considered within the $10 \mu \mathrm{l}$ corresponding to the addition of this $10 \mu \mathrm{l}$ of Lysis buffer.

3. Add to each tube $10 \mu \mathrm{l}$ of PKA fraction, except for the Negative control, in which PKA fraction should be replaced by $10 \mu$ of Lysis buffer.

4. Keep all tubes on ice until used.

From Step D5 onwards the procedures must be performed in the radioisotope room. Please note that security measures must be taken when working with radioactive material. Proper shielding for the personnel is required, as well as adequate waste disposal according to institutional regulations.

5. Complete preparation of the Kinase buffer by adding the proper amount of ATP- ${ }^{32} \mathrm{Py}$ (see Table 1 ), taking into consideration of the decay time and manufacture date, then add $1 \mu \mathrm{Ci} /$ assay. 
Table 1. Stock solutions and concentration for the preparation of Kinase buffer

\begin{tabular}{|c|c|c|c|c|c|}
\hline Reagent & $\begin{array}{l}\text { Final concentration in } \\
\text { reaction tube }(30 \mu \mathrm{l})\end{array}$ & $\begin{array}{l}\text { Stock } \\
\text { concentration }\end{array}$ & $\begin{array}{l}\text { Concentration in } \\
3 x \text { Kinase buffer }\end{array}$ & $\begin{array}{l}\text { Vol of stock for } 3 x \\
\text { Kinase buffer }(\mu l)\end{array}$ & Notes \\
\hline $\begin{array}{l}\text { Distilled } \\
\text { water }\end{array}$ & - & - & & 24.85 & - \\
\hline HEPES & $25 \mathrm{mM}$ & $\begin{array}{l}200 \mathrm{mM}, \mathrm{pH} \\
7.3\end{array}$ & $75 \mathrm{mM}$ & 131.25 & - \\
\hline G3P & $40 \mathrm{mM}$ & $800 \mathrm{mM}$ & $120 \mathrm{mM}$ & 52.5 & - \\
\hline BSA & $1 \mathrm{mg} / \mathrm{ml}$ & $50 \mathrm{mg} / \mathrm{ml}$ & $3 \mathrm{mg} / \mathrm{ml}$ & 21 & - \\
\hline $\mathrm{MgCl}_{2}$ & $10 \mathrm{mM}$ & $1 \mathrm{M}$ & $30 \mathrm{mM}$ & 10.5 & - \\
\hline $\mathrm{Na}_{3} \mathrm{VO}_{4}$ & $100 \mu \mathrm{M}$ & $100 \mathrm{mM}$ & $300 \mu \mathrm{M}$ & 1.05 & - \\
\hline NPP & $5 \mathrm{mM}$ & $500 \mathrm{mM}$ & $15 \mathrm{mM}$ & 10.5 & - \\
\hline IBMX & $0.1 \mathrm{mM}$ & $\begin{array}{l}100 \mathrm{mM} \text { (in } \\
\mathrm{DMSO})\end{array}$ & $0.3 \mathrm{mM}$ & 1.05 & - \\
\hline cAMP & $1 \mathrm{mM}$ & $1 \mathrm{M}$ & $3 \mathrm{mM}$ & 1.05 & - \\
\hline ATP & $40 \mu \mathrm{M}$ & $1 \mathrm{mM}$ & $120 \mu \mathrm{M}$ & 42 & \\
\hline $\begin{array}{l}{ }^{*} \text { Protease } \\
\text { inhibitor }\end{array}$ & $1 x$ & $25 x$ & $2 x$ & 28 & $\begin{array}{l}{ }^{*} \text { Add just } \\
\text { before use }\end{array}$ \\
\hline${ }^{*}$ Kemptide & $100 \mu \mathrm{M}$ & $5 \mathrm{mM}$ & $300 \mu \mathrm{M}$ & 21 & \\
\hline${ }^{* *} \mathrm{ATP} \_{ }^{32} \mathrm{Py}$ & $1 \mu \mathrm{Ci} /$ assay & $10 \mu \mathrm{Ci} / \mu \mathrm{l}$ & $3 \mu \mathrm{Ci} /$ assay & 5.25 & $\begin{array}{l}{ }^{* *} \text { Add in the } \\
\text { radioisotope } \\
\text { room }\end{array}$ \\
\hline Total Volume & & & & 350 & - \\
\hline
\end{tabular}

\section{Notes:}

a. All reagents are dissolved in distilled water, unless specified otherwise.

b. The protease inhibitor cocktail is added as to prepare a $2 x$ concentrated buffer, since the PKA fraction already contains cocktail.

c. Addition of BSA is done to help precipitate all proteins after TCA addition, but keeping the Kemptide soluble.

6. Sequentially add $10 \mu \mathrm{l}$ of Kinase buffer to all tubes and place them at $37^{\circ} \mathrm{C}$. Start a new reaction every $30 \mathrm{~s}$ by adding $10 \mu \mathrm{l}$ of Kinase buffer. Keep track of the sequential order of all tubes. This is crucial in order to stop the reactions exactly at the specified time.

7. Incubate tubes at $37^{\circ} \mathrm{C}$ for $30 \mathrm{~min}$.

8. Stop the reaction after $30 \mathrm{~min}$ by addition of $10 \mu \mathrm{l} 40 \%$ TCA. Note that the total volume in each tube now is $40 \mu \mathrm{l}$. 
9. Incubate tubes on ice for $20 \mathrm{~min}$.

10. Centrifuge at $10,000 \times g$ for $3 \mathrm{~min}$, at RT.

11. For each tube, take $10 \mu$ of the supernatant, and spot onto the center of a P81 piece of paper, while holding it with tweezers (Figures 2A and 2B). Each piece of P81 paper should be labeled with pencil in order to identify them later. Wait $5 \mathrm{~s}$ for the drop to be absorbed, and release it in a $5 \mathrm{~L}$ beaker containing $1 \mathrm{~L}$ of $5 \mathrm{mM}$ ortho-phosphoric acid (Figure $2 \mathrm{C}$ ).

12. Wash together all papers $6 \times 5$ min using $1 \mathrm{~L}$ of $5 \mathrm{mM}$ ortho-phosphoric acid each time, in a beaker placed on an orbital shaker.

13. While the washing in Step D12 proceeds, spot $1 \mu \mathrm{l}$ of Kinase buffer on a P81 paper. Do this in triplicate using 3 different papers, and then directly insert each one in a different plastic vial, without washing. This step is necessary for data analysis to calculate the total amount of total ATP- ${ }^{32} \mathrm{Py}$, initially present in the reaction media.

14. After washing, place the $P 81$ papers on a plastic tray, without contact between each other, and let them air dry for at least $2 \mathrm{~h}$ (Figure 2D). At this step, you can discontinue the protocol until the next day. Papers are identified according to the pencil mark written on them before spotting the reaction mixture.

15. Once dried, place papers individually in a plastic vial, containing $1 \mathrm{ml}$ of scintillation counter liquid, and register counts per minute (CPM) a vial counter.
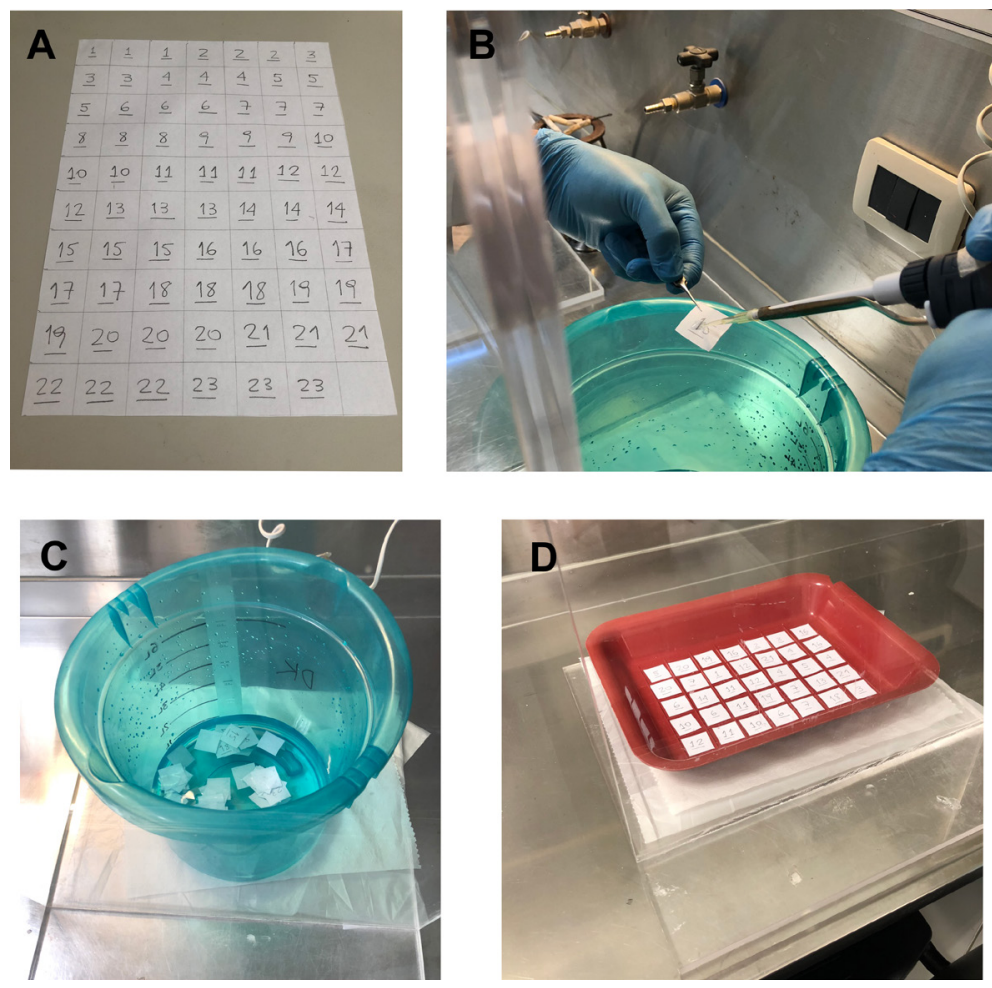

Figure 2. P81 paper spotting. A. Prepare $2 \times 2 \mathrm{~cm}$ P81 papers labeled with pencil marks. B. Spot each paper with $10 \mu \mathrm{l}$ the supernatant of the reaction mixture after centrifugation (Step D11). Notice that the washing is being performed behind the protecting shield in a radioisotopes 
room. C. Place one by one all the papers in the same beaker with $1 \mathrm{~L}$ of $5 \mathrm{mM}$ ortho-phosphoric acid (Step D11). D. Let all pieces to air dry without touching each other.

\section{Data analysis}

On an Excel file, write down counts per minute (CPM) values of each condition, obtained in step D15 (Table 2). These measures correspond to the $10 \mu \mathrm{l}$ of the supernatant of the reaction mixture spotted on P81 paper.

Table 2. In vitro PKA kinase assay data analysis. Schematic view of steps A-H for data processing.

\begin{tabular}{|c|c|c|c|c|c|c|}
\hline & & $\begin{array}{l}\text { 1/10 Kinase } \\
\text { buffer control }\end{array}$ & Negative control & Positive control & Test sample 1 & Test sample $\mathrm{n}$ \\
\hline & & A & B & C & D & E \\
\hline CPM read 1 & 1 & A1 & B1 & $\mathrm{C} 1$ & D1 & E1 \\
\hline $\begin{array}{l}\text { CPM read } 2 \\
\text { (duplicate) }\end{array}$ & 2 & $\mathrm{~A} 2$ & B2 & $\mathrm{C} 2$ & $\mathrm{D} 2$ & E2 \\
\hline $\begin{array}{l}\text { CPM read } 3 \\
\text { (triplicate) }\end{array}$ & 3 & A3 & B3 & $\mathrm{C} 3$ & D3 & E3 \\
\hline Mean & 4 & $(\mathrm{~A} 1+\mathrm{A} 2+\mathrm{A} 3) / 3$ & $(\mathrm{~B} 1+\mathrm{B} 2+\mathrm{B} 3) / 3$ & $(\mathrm{C} 1+\mathrm{C} 2+\mathrm{C} 3) / 3$ & $(\mathrm{D} 1+\mathrm{D} 2+\mathrm{D} 3) / 3$ & $(\mathrm{E} 1+\mathrm{E} 2+\mathrm{E} 3) / 3$ \\
\hline Corrected mean & 5 & - & - & C4-B4 & D4-B4 & E4-B4 \\
\hline \multicolumn{7}{|c|}{ Dilution factor $(\mathrm{df})=$ Total volume in reaction tube $/$ Volume spotted on P81 } \\
\hline Total CPM in tube & 6 & A4 $\times 10$ & - & $\mathrm{C} 5 \mathrm{xdf}$ & D5 $x \mathrm{df}$ & E5 $x \mathrm{df}$ \\
\hline \multicolumn{7}{|c|}{ CPM of A6 are representative of the $\rho$ mols of ATP ("a") added to the reaction medium } \\
\hline \multicolumn{7}{|c|}{ Mixtures contains "b" CPM/pmol ATP, equivalent to (A4/"a")/1000 } \\
\hline $\begin{array}{l}\text { Incorporated ATP } \\
\text { during the reaction } \\
(\rho \mathrm{mol})\end{array}$ & 7 & - & - & C6/"b" & D6/"b" & $\mathrm{E} 6 / " \mathrm{~b}$ \\
\hline $\begin{array}{l}\text { Incorporated ATP } \\
\text { in the reaction per } \\
\mathrm{min}(\rho \mathrm{mol} / \mathrm{min})\end{array}$ & 8 & - & - & $\mathrm{C} 6 / 30$ & $\mathrm{D} 6 / 30$ & $\mathrm{E} 6 / 30$ \\
\hline
\end{tabular}

1. Calculate the mean value (mean) for each condition considering the experimental triplicates.

2. Obtain the corrected mean by subtracting the negative control mean from all means, except for the Kinase buffer mean. 
Please cite this article as: Stival et. al., (2020). Quantification of Protein Kinase A (PKA) Activity by An in vitro Radioactive Assay Using the Mouse Sperm Derived Enzyme,Bio-protocol 10 (12): e3658. DOI: 10.21769/BioProtoc.3658.

3. Adjust the mean CPM value of each condition to the total volume of the assay $(40 \mu \mathrm{l})$ by multiplying the corrected mean by 4 , since you put $10 \mu \mathrm{l}$ on the P81 papers out of $40 \mu \mathrm{l}$.

4. Use the Kinase buffer mean CPM to determine the total amount of ATP_32PY present in each reaction tube. This will be used to address the amount of ${ }^{32} \mathrm{P}$ incorporated into the Kemptide. To do this, first multiply the mean CPM value of the Kinase buffer by the dilution factor (in this case it is a factor of 10 since you spotted $1 \mu \mathrm{l}$ of Kinase buffer out of $10 \mu \mathrm{l}$ present in the reaction).

5. To determine how many [CPM/pmol ATP], noted as "b" in Table 2, are in the mixture, divide by the total ATP moles added (in this case the reaction mixture contained 800 pmol of ATP, noted as "a" in Table 2).

6. To determine how many pmoles of ATP were incorporated in each condition, divide total CPM of each condition by [CPM/pmol ATP] of the mixture.

7. To determine how many pmoles of ATP were incorporated in each condition per minute, divide this last value by the time of the reaction. In this case divide by 30 , since the reaction lasted 30 minutes.

8. Report this value considering the amount of sperm used for each condition. Please see Table 3 for an example of results.

Table 3. Example of results. The table exemplifies results obtained using the PKA inhibitor H-89 (Sigma \#B1427, diluted in DMSO), at the concentrations specified.

Note: In this example, all tubes contained cAMP and IBMX (see Table 1).

\begin{tabular}{|c|c|c|c|c|c|c|c|c|c|}
\hline & \multirow{2}{*}{$\begin{array}{l}1 / 10 \\
\text { Kinase } \\
\text { buffer } \\
\text { control }\end{array}$} & \multirow[b]{2}{*}{$\begin{array}{l}\text { Negative } \\
\text { Control }\end{array}$} & \multicolumn{6}{|c|}{ H89 ( $\mu M)$} \\
\hline & & & & $\begin{array}{l}0 \text { (positive } \\
\text { control) }\end{array}$ & 0.1 & 1 & 10 & 50 & 100 \\
\hline \multirow{3}{*}{ CPM reads } & replicate 1 & 275374 & 10172 & 303106 & 321092 & 239832 & 44063 & 12470 & 11207 \\
\hline & replicate 2 & 285443 & 11604 & 333105 & 327384 & 209389 & 48771 & 10125 & 12164 \\
\hline & replicate 3 & 239039 & 10563 & 313784 & 32639 & 219980 & 43795 & 12634 & 10993 \\
\hline & mean & 266618.67 & 10779.67 & 316665.00 & 227038.33 & 223067.00 & 45543.00 & 11743.00 & 11454.67 \\
\hline \multicolumn{2}{|c|}{ mean - negative control } & & \multirow[t]{2}{*}{0.67} & 305886.00 & 216259.33 & 212288.00 & 34764.00 & 964.00 & 675.67 \\
\hline \multicolumn{2}{|c|}{ total CPM $(10 \mu \mathrm{l}$ of $40 \mu \mathrm{l})$} & & & 1223544.00 & 865037.33 & 849152.00 & 139056.00 & 3856.00 & 2702.67 \\
\hline \multicolumn{10}{|c|}{800 pmoles of ATP represents 2666190 CPM } \\
\hline \multicolumn{10}{|c|}{ Thus, mixtures contains $3332.7 \mathrm{CPM} / \mathrm{pmol}$ ATP } \\
\hline \multicolumn{4}{|c|}{ incorporated pmol of ATP in the reaction (pmol) } & 367.13 & 259.56 & 254.79 & 41.72 & 1.16 & 0.81 \\
\hline \multicolumn{4}{|c|}{$\begin{array}{l}\text { incorporated pmol of ATP in the reaction per min } \\
(\mathrm{pmol} / \mathrm{min})\end{array}$} & 12.24 & 8.65 & 8.49 & 1.39 & 0.04 & 0.03 \\
\hline \multicolumn{4}{|c|}{$\begin{array}{l}\text { Since each tube contains } 2.40 \mathrm{E} 5 \mathrm{sperm} \text {, then } \\
\text { incorporated ATP in the reaction ( } \mathrm{pmol} / \mathrm{min} / 5 \mathrm{E} 6 \mathrm{sperm})\end{array}$} & 254.91 & 180.22 & 176.91 & 28.97 & 0.80 & 0.56 \\
\hline
\end{tabular}




\section{Recipes}

1. H-TYH medium

General composition:

$119.3 \mathrm{mM} \mathrm{NaCl}$

$4.7 \mathrm{mM} \mathrm{KCl}$

$0.8 \mathrm{mM}$ Na-Pyruvate

$1.71 \mathrm{mM} \mathrm{CaCl}_{2}$

$1.2 \mathrm{mM} \mathrm{KH}_{2} \mathrm{PO}_{4}$

$1.2 \mathrm{mM} \mathrm{MgSO}_{4}$

$5.4 \mathrm{mM}$ glucose

$20 \mathrm{mM}$ HEPES

$\mathrm{pH}=7.2-7.4$

To prepare $25 \mathrm{ml}$ of buffer, weight:

$\begin{array}{lr}\mathrm{NaCl} & 174.3 \mathrm{mg} \\ \mathrm{KCl} & 8.76 \mathrm{mg} \\ \mathrm{CaCl}_{2} \cdot 2 \mathrm{H}_{2} \mathrm{O} & 6.28 \mathrm{mg} \\ \mathrm{KH}_{2} \mathrm{PO}_{4} & 4.08 \mathrm{mg} \\ \mathrm{MgSO}_{4} \cdot 7 \mathrm{H}_{2} \mathrm{O} & 7.39 \mathrm{mg} \\ \mathrm{HEPES} & 119.15 \mathrm{mg}\end{array}$

a. Dissolve all reagents in Mili- $Q$ water to a final volume of $25 \mathrm{ml}$

b. Sterilize by filtration using a $0.45 \mu \mathrm{m}$ filter and store at $4{ }^{\circ} \mathrm{C}$ up to 1 month

c. On the day of use, add $2.20 \mathrm{mg}$ Sodium Pyrutave and $24.78 \mathrm{mg}$ Glucose

d. Bring to a final $\mathrm{pH}$ of 7.2-7.4 with freshly prepared $5 \mathrm{~N} \mathrm{NaOH}$

2. Lysis buffer (prepare day of use)

General composition:

$25 \mathrm{mM}$ Tris $\mathrm{pH} 7.4$

$150 \mathrm{mM} \mathrm{NaCl}$

1x Cocktail protease inhibitor (EDTA-free, SIGMA)

$1 \%$ Triton X-100

To prepare $900 \mu$ l of buffer:

$\begin{array}{lr}1 \mathrm{M} \text { Tris, } \mathrm{pH} 7.4 & 22.5 \mu \mathrm{l} \\ 3 \mathrm{M} \mathrm{NaCl} & 45 \mu \mathrm{l} \\ \text { 25x Cocktail protease inhibitor } & 36 \mu \mathrm{l} \\ \text { Triton X-100 } & 9 \mu \mathrm{l} \\ \text { Distilled water } & 787.5 \mu \mathrm{l}\end{array}$

3. $100 \mathrm{mM}$ IBMX

Dissolve $22.22 \mathrm{mg}$ in $1 \mathrm{ml}$ of DMSO

4. Kinase buffer 
Prepare $3 x$ Kinase buffer as it will be diluted 3 times by addition of 1 volume (10 $\mu$ l) of PKA fraction plus 1 volume of buffer solution (10 $\mu$ ), accounting for $30 \mu \mathrm{l}$ of reaction tube (see Table 1). The following volumes are calculated to prepare the amount of buffer needed for 30 reaction tubes (10 different conditions in triplicates), considering that $10 \mu \mathrm{l}$ of Kinase buffer is added to each tube.

\section{Acknowledgments}

The work was funded by Agencia Nacional de Promoción Científica y Tecnológica, PICT 2015-3164 and 2017-3217 awarded to DK. The heptapeptide known as Kemptide was synthesized for the first time by Kemp et al, to study the specificity of the PKA towards its substrate (Kemp et al., 1977). The adapted protocol described in that manuscript has used for the first time by Visconti et al. (1997)

\section{Competing interests}

The authors declare no competing interests.

\section{Ethics}

Cauda epididymides were collected from C57BL/6 young adult male mice (8-20 weeks old) and sacrificed under supervision of the Animal Care and Use Committee of the Facultad de Ciencias Bioquímicas y Farmacéuticas de Rosario (UNR) (approved protocol numbers 7298/532).

\section{$\underline{\text { References }}$}

1. Akamine, P., Madhusudan, Wu, J., Xuong, N. H., Ten Eyck, L. F. and Taylor, S. S. (2003). Dynamic features of cAMP-dependent protein kinase revealed by apoenzyme crystal structure. J Mol Biol 327(1): 159-171.

2. Buffone, M. G., Wertheimer, E. V., Visconti, P. E. and Krapf, D. (2014). Central role of soluble adenylyl cyclase and cAMP in sperm physiology. Biochim Biophys Acta 1842(12 Pt B): 26102620.

3. Kemp, B. E., Graves, D. J., Benjamini, E. and Krebs, E. G. (1977). Role of multiple basic residues in determining the substrate specificity of cyclic AMP-dependent protein kinase. $J$ Biol Chem 252(14): 4888-4894.

4. Krapf, D., Arcelay, E., Wertheimer, E. V., Sanjay, A., Pilder, S. H., Salicioni, A. M. and Visconti, P. E. (2010). Inhibition of Ser/Thr phosphatases induces capacitation-associated signaling in the presence of Src kinase inhibitors. J Biol Chem 285(11): 7977-7985. 
5. Stival, C., Puga Molina Ldel, C., Paudel, B., Buffone, M. G., Visconti, P. E. and Krapf, D. (2016). Sperm capacitation and acrosome reaction in mammalian sperm. Adv Anat Embryol Cell Biol 220: 93-106.

6. Stival, C., Ritagliati, C., Xu, X., Gervasi, M. G., Luque, G. M., Baro Graf, C., De la Vega-Beltran, J. L., Torres, N., Darszon, A., Krapf, D., Buffone, M. G., Visconti, P. E. and Krapf, D. (2018). Disruption of protein kinase A localization induces acrosomal exocytosis in capacitated mouse sperm. J Biol Chem 293(24): 9435-9447.

7. Visconti, P. E., Moore, G. D., Bailey, J. L., Leclerc, P., Connors, S. A., Pan, D., Olds-Clarke, P. and Kopf, G. S. (1995). Capacitation of mouse spermatozoa. II. Protein tyrosine phosphorylation and capacitation are regulated by a cAMP-dependent pathway. Development 121(4): 11391150.

8. Visconti, P. E., Johnson, L. R., Oyaski, M., Fornes, M., Moss, S. B., Gerton, G. L. and Kopf, G. S. (1997). Regulation, localization, and anchoring of protein kinase A subunits during mouse sperm capacitation. Dev Biol 192(2): 351-363.

9. Zhang, P., Smith-Nguyen, E. V., Keshwani, M. M., Deal, M. S., Kornev, A. P. and Taylor, S. S. (2012). Structure and allostery of the PKA Rllbeta tetrameric holoenzyme. Science 335(6069): 712-716. 